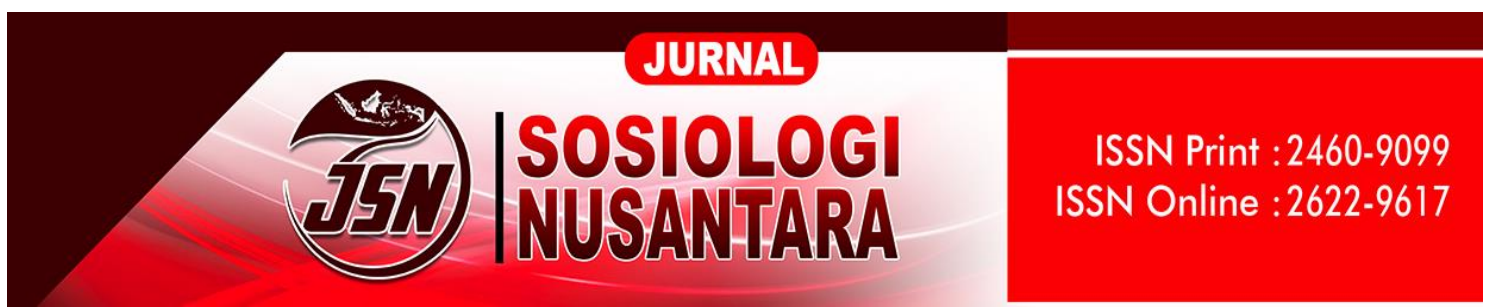

https://ejournal.unib.ac.id/index.php/jsn

DOI ://doi.org/10.33369/jsn.7.2.193-204

\title{
CONSUMPTIVE LIFESTYLE BEHAVIOUR OF ADOLESCENT IN INDONESIA IN INDUSTRIAL REVOLUTION 4.0
}

\author{
Firman Mansir ${ }^{1}$, Amalia Undip Putri $\mathbf{M}^{2}$ \\ firmanmansir@umy.ac.id, amaliaundipputri@gmail.com \\ 1. Universitas Muhammadiyah Yogyakarta \\ 2.Universitas Islam Indonesia
}

\begin{abstract}
This research explains that adolescents are a social commodity with consumptive behaviour that has affected all circles of society. The problem is that adolescents tend to always to want have and buy expensive items. This research aimed to determine the consumptive lifestyle behaviour of adolescents in the industry 4.0 in use the development of technology and information. The method used was in the form of qualitative research. With the type of literature study with the researcher as the main instrument, it was strengthened by the instrument of documentation about literature regarding consumptive adolescents. The results showed that the consumptive behaviour of adolescents in the industry 4.0 can be seen that they buy goods that is not to fulfill their needs but to fulfill their desires. Thus, what they are excessive and it leads to extravagant, and excessive nature.
\end{abstract}

Keywords : Industrial Revolution 4.0, Lifestyle, Youth Behaviour

\section{INTRODUCTION}

In this globalization era, various sectors such as economics, technology, industry and others have progressed very rapidly. The existence of this progress will certainly ease people to do things. For example, in the economic field, people are no longer having trouble finding the products or goods they will need. It is due to the increasing level of production and circulation of goods and services offered to the public (Sukari et al., 2013). The number of goods and services on the market will certainly affect the goods and services offered to the public. There are also various attitudes of individuals in purchasing and using goods. Thus, the purchase and use of an item is sometimes no 
longer to meet needs but is driven because of a desire factor that is useless, such as following trends, prestige, increasing prestige, and various other reasons that are considered less important. Thus, it will not directly cause purchasing power and consumptive attitude will increase.

Nowadays, consumptive behaviour is known in all circles of society, including adolescent. Based on (Santrock, 2011), In adolescence, individuals will tend to like new things that are challenging for themselves. It is because adolescents are trying to achieve independence and find their identity. Meanwhile, the emergence of several changes that may be experienced by adolescents are either physical, attitudes, behaviour, and emotions changes. Emotional intelligence can be developed through education (Mansir, 2021), such as Islamic education (Mansir \& Karim, 2020). One of them is a change in behaviour that tends to be consumptive (Sukari et al., 2013).

Explained that consumptive behaviour is a desire to consume goods that are actually less needed in excess to achieve maximum satisfaction (Nurjanah et al., 2018). This is because there are many adolescents who fulfill more satisfaction to look much cooler in front of their friends so as to make them achieve their own satisfaction. Besides, in society, it can't be separated from the influence of consumptive behaviour, thus, teenagers become the target of various company products.

Adolescents are group of individuals in the age range of 12-21 years with the division into three periods, such as early adolescence aged 12-15, middle adolescence aged 15-18 (Monks \& Knoers, 2014). At this age, adolescents experience both physical and psychological changes. It occurs so fast and it is greatly influenced by changing trends and fashions. One of the tasks of adolescent development according to Haviguhurst (Hurlock, Elizabeth b, Istiwidayanti, Sijabat, 1991) is to start preparing for economic freedom. At this stage, adolescents are required to start practicing to achieve the ability to stand alone that is suitable and in accordance with their choices and tastes.

Adolescents tend to always want to have these expensive items and excessive in buying or consuming. The attitude and behaviour of adolescent who consume goods excessively and unnaturally is what is called consumptive behaviour. Consumptive behaviour that often occurs in young women is generally only limited to the desire for these items and not according to needs. besides, young women are more consumptive towards clothes with well-known brands. Clothing with well-known brands is 
considered to be of much higher quality and more able to increase self-confidence, especially when they wear them (Lina \& Rosyid, 1997).

This research aimed to find out the consumptive lifestyle behaviour of teenagers in the industry 4.0, in utilizing the development of technology and information, consumptive behaviour and following current trends. The description of the data is divided into 3 major parts, such as data on the consumptive lifestyle of adolescents, the industrial revolution 4.0, and data on the relation between two variables, namely the consumptive lifestyle of adolescents in the industrial era 4.0. Thus, the writing of this research report consistwd of an introduction that reviewed the background of the root of the problem, the methodology section that contained the stages of searching for data and its analysis, findings and discussions and conclusions.

\section{RESEARCH METHOD}

This research method used library research by collecting data from writings (literacy) that were related to the topics discussed (Sugiyono, 2013). The sources came from library materials (Rukajat, 2018). The data collection process was carried out by collecting books, articles and online journals as well as online websites that were in accordance with the issues raised, namely the consumer behaviour of teenagers who focus on the use of technology and information developments. After the data were collected, a selection was made between books, journals and articles, both physical and e-books and e-journals that discuss consumer behaviour in adolescents (Trianto, 2010). The collected data will be validated by matching literature from primary and secondary sources and analyzed with content analysis and descriptive analytic (Sugiyono, 2013). Descriptive analysis fulfilled at least the stages of collecting, screening, displaying, and interpreting the collected data. The preparation of this article was determined and carried out with several improvements in the systematics of writing and accompanied by data obtained from several related sources. Thus, this article can be presented in a coherent manner and can be easily understood. Then, it presented critically through primary and secondary library sources related to the theme. 


\section{DISCUSSION}

\section{a. Consumptive Lifestyle of Adolescent}

The consumptive lifestyle of adolescents currently has become part of the millennial soul. No wonder, various advertisements for goods and services are familiar to adolescent the industrial era 4.0 through social media. The invitation to shop has appeared since people wake up, have activities, become consumption until they use the services provided by adolescents in the industrial era 4.0 in the sense that they prefer to spend money to buy a product. Thus, adolescents of the industrial 4.0 era are consumers who dominate the market today. Hence, it is not surprising that many people make business opportunities in selling online.

According to (Sukari et al., 2013) stated that the concept of consumptive behaviour is very varied, but the notion of consumptive behaviour is buying goods or services without rational consideration or not on the basis of needs. According to (Rosyid, 1997), consumptive behaviour is the act of buying goods and not to fulfill needs but to fulfill desires, that is conducted excessively, causing waste and cost inefficiency. The consumptive behaviour is formed because consumptiveness has become part of the lifestyle process. Meanwhile, consumerism emerged especially after the industrialization period where goods were mass produced so that they needed the internet, both electronic and mass, in this case, they occupy a strategic position in shaping consumptive behaviour, namely as a medium that attracts consumers' interest in buying consumptive goods.

The media places adolescents as the target of a strategy that has a major influence on societal change. For example, electronic media such as the internet that can access various online shopping and see advertisements for all kinds of products indirectly raises suggestions in their minds to have an item. Besides, there is attractive product display with additional discounts used by business people as their tactic in trading their products, it is one of the tactics in trading (Fryzia, n.d.).

Based on (Mulyodiharjo, 2002), the characteristics or indicators of consumptive behaviour are as follows:

1) Purchasing products because of the lure of gifts.

The purchase of goods does not see the benefits, but the purpose is only to obtain the prizes offered. 
2) Purchasing the product because the packaging is attractive.

Individuals are interested in buying an item because the packaging is different from the others. The packaging of an item that is attractive and unique will make someone buy the item.

3) Purchasing products to maintain a prestige appearance.

Prestige makes individuals prefer to buy items that are considered to be able to maintain their appearance, compared to buying other items that are more needed.

4) Purchasing products based on price considerations (not on the basis of benefits),

Consumers tend to behave consumptive that is indicated by the existence of a luxurious life. Thus, they tend to use everything considered the most luxurious.

5) Purchasing a product just to keep the symbol or status.

Individuals consider the goods used are a symbol of their social status. By buying a product, they can give a status symbol to make it look cooler in the eyes of others.

6) Using the product because of the element of confirmation of the model that advertises the product. Individuals use an item because they are interested in being like the advertising model, or because the advertised model is an idol of the buyer.

7) The emergence of an assessment that buying products at high prices will lead to self-confidence. Individuals buy goods or products not based on needs but because they have an expensive price to increase their confidence.

8) Desire to try more than two different similar products.

Consumers will tend to use products of the same type as other brands from the products they previously used, even though the product has not been used up.

Consumptiveness is the desire to consume goods that are actually less needed in excess to achieve maximum satisfaction (Mansir, 2018). Thus, adolescents only see from the side of pleasure and prioritizes priorities rather than needs (Mansir, 2017). In addition, this behaviour does not indicate a need factor in it. Adolescents seem to 
clearly behave consumptively to support self-esteem in relationships without looking at their actual needs. The phenomenon of the consumptive lifestyle of adolescents is certainly very concerning. This can't be left alone because consumptive behaviour since adolescence can encourage cultural changes in the community. Thus, the need for internal factors such as self-control needs to be controlled from within the individual based on self-awareness. While external factors are carried out by the environment both from the family or social groups where individuals interact (Mansir \& Syarnubi, 2021). Piety and social obedience can be shaped by the surrounding educational environment, especially the pesantren environment (Karim et al., 2020). The family environment, especially parents, is expected to continue to provide constructive input and motivation while monitoring the relationships of adolescents and establishing communication and understanding between the two parties to understand each other. Likewise, a student's motivation for success can be established by the environment that surrounds him (Qodriah et al., 2019).

\section{b. Industrial Revolution 4.0}

The term Industry 4.0 was appeared from the idea of the fourth industrial revolution. European Parliamentary Research Service in (Basuki, 2018) stated that the industrial revolution occurred four times. The first industrial revolution occurred in England in 1784 where the invention of the steam engine and mechanization began to replace human work. The second revolution occurred at the end of the $19^{\text {th }}$ century in which production machines powered by electricity were used for mass production activities. The use of computer technology for manufacturing automation starting in the 1970s marked the third industrial revolution. The use of tools produced from advanced information and technology can actually form a phubbing attitude in students, but that is part of social interaction in this era (Afnan et al., 2020).

In addition, advanced communication tools can also be used as a means for learning (Suzana et al., 2020). Nowadays, the rapid development of sensor technology, interconnection, and data analysis has given rise to the idea of integrating all these technologies into various industrial fields. This idea is predicted to be the next industrial revolution. The number four in the term Industry 4.0 refers to the fourth revolution. Industry 4.0 is a unique phenomenon when compared to the three industrial revolutions that preceded it. 
Industrial revolution 4.0 is a new chapter in the industry that will involve more digital technology (Mansir, 2020). Estimating the existence of the industrial revolution will bring several impacts on industrial processes and human life such as innovation, competitiveness, management, security and technology users of the Ministry of Industry of the Republic of Indonesia. Therefore, there is a need for anticipation in facing industry 4.0 that will be all digital in the future, one of which is in the small and medium industrial sector (IKM), because according to the Ministry of Industry, there will be the use of digital technology to spur productivity and competitiveness for small and medium industries to be able to face global competition.

Ministry of Industry (Febriantika et al., 2019) has determined that there are four strategic steps in facing Industry 4.0. The steps that will be carried out are:

1. Encouraging the workforce in Indonesia to continue to improve their abilities and skills, especially in using internet of things technology or integrating internet capabilities with industrial production lines.

2. Utilization of digital technology to spur productivity and competitiveness for small and medium-sized industries (IKM) to be able to penetrate the export market through the e-smart IKM program.

3. Optimizing the use of digital technology in national industries such as Bhig Data, Autonomous Robots, cybersecurity, Cloud, and Augmented Reality.

4. Encouraging technological innovation through the development of start-ups by facilitating business incubation so that there are more technology-based entrepreneurs in the territory of Indonesia.

By implementing Industry 4.0, the Minister of Industry targets that the big national vision can be achieved. The vision in outline is to bring Indonesia into the top 10 economies by 2030. Thus, it can return the industry's net export rate of 10 percent, increase labor productivity to double the increase in labor costs, and allocate two percent of GDP for research and development. technology and innovation development, or seven times from today.

Entering the era of the industrial revolution 4.0, of course we are in a modern era. The concept of industry 4.0 was first used in public in 2011, precisely at the Hannover Messe industry exhibition, Hannover. After we have known the revolution in industry 
that began in the $18^{\text {th }}$ century until now, therefore let us discuss 4 important principles in industry 4.0, as follow:

a. Interconnection, the first principle in the 4.0 industrial revolution is the interconnection or relation between humans, tools and machines in communicating with each other with the Internet of Things (IOT) or Internet of People (IOP).

b. Information Transportation, existing technology certainly allows and eases individuals to collect various types of important data in the production process to help make decisions. The principle of interconnection also helps one in identifying which areas need to get a touch of innovation in the production process.

c. Technical Assistance, the third principle is technical assistance with relevant and important information to make an informed decision and solve problems quickly. In addition, the presence of a cyber physical system will assist humans in completing heavy and dangerous work if done manually

d. Decision Making, Cyber physical system will decide automatically in carrying out tasks according to the correct function without requiring intervention from external parties.

From some of the concepts above, the application can advance communication technology and have the will to think ahead. In addition, it can help all sectors in innovating, especially in the field of MSMEs and can establish relationships with stakeholders for economic growth in Indonesia.

\section{c. Adolescents' Consumptive Lifestyle in the Industrial Age 4.0}

Consumptive behaviour is formed because consumptive has become a lifestyle as part of a wider process (Mansir, 2018). Meanwhile, consumptive behaviour emerged especially after the industrialization period where goods were mass-produced so that they needed media, both electronic and mass, in shaping consumptive behaviour, namely as a medium that attracted consumers' interest in buying consumptive goods. Social changes that occur are influenced by factors that can change a person's behaviour, in this case being more consumptive, one of the most influencing factors in this era is the media factor, information that is growing rapidly at this time occurs 
because of technological advances through the internet. Thus, many teenagers are tempted by advertisements on social media, making them interested in buying a product that doesn't actually need to be purchased.

Consumptive behaviour in adolescents is no longer based on the need factor, it can be seen from the characteristics of their consumptive behaviour. The characteristics of adolescent consumptive behaviour according to (Astasari \& Sahrah, 2006), can be seen from the characteristics of teenage buyers are as follow:

1. Teenagers are very easily influenced by the salesperson's seduction

2. Easily persuaded by advertisements, especially on the neatness of the wrapping paper (especially if it is decorated with attractive colors)

3. They do not think about thriftiness

4. Less realistic, romantic, and easily persuaded (impulsive)

The desire factor is the basis for adolescents to carry out these actions, the characteristics mentioned above are quite illustrative. Besides, showing the need factor in this behaviour is not at all to support self-esteem in relationships without looking at the actual needs of teenagers, it seems clear that they behave consumptively. In addition, the characteristics or characteristics of adolescents who behave consumptively are an important basis for recognizing and studying further about consumptive behaviour, which has been explained in the previous discussion. This is because by studying and understanding the characteristics of teenagers who behave consumptively, it will be known the factors that cause them to behave consumptively, thus, it will be able to know the factors that cause them to behave consumptively.

Hence, the lifestyle of teenagers in the industrial era 4.0 will have a negative impact on this consumptive behaviour so that the appearance of wasteful, dependent, and dissatisfied with the results achieved. Thus, to avoid the negative impact of consumptive behaviour on teenagers, it is necessary to save or invest (Khoirunnas \& Hidir, 2017). A wise attitude towards all kinds of promotion of goods and services on the internet, especially on social media, is needed for every consumer. Therefore, it is necessary to have an attitude of curiosity towards goods and services to be purchased in the form of seeking information so that they are more confident about the good and bad of a product. Besides, consumers also need to know more about whether the goods to be 
purchased are a need or just a desire to know the benefits. With these efforts, the consumer behaviour of teenagers in the industrial 4.0 era can be minimized.

\section{CONCLUSION}

The consumptive behaviour of adolescents in the industrial era 4.0 is purchasing goods not to fulfill their needs but to fulfill their desires. Thus, what they do is excessive and it creates extravagant. In addition, consumptive behaviour is formed because consumptiveness has become part of the lifestyle process. Meanwhile, consumptive behaviour has already existed when there was a period of industrialization where goods were mass-produced so that they needed a wider range of consumers. Characteristics during adolescence affect their mentality to become consumptive behaviour. Besides, a adolescents can be influenced by several aspects that underlie wasteful behaviour, both internal factors and external factors.

\section{REFERENCE}

Afnan, D., Karim, A., Irfan, A., Rianto, A., Wildanu, E., Hidayat, R., Aziza, D. K., Kardiyanti, E. N., Rengganis, A., Kamaluddin, M., \& Mar'ati, A. (2020). Phubbing and social interaction: An analysis of smartphone usage in higher education. Journal of Advance Research in Dynamical \& Control Systems, 12(6), 2325-2334. https://doi.org/10.5373/JARDCS/V12I6/S20201191

Astasari, A. R., \& Sahrah, A. 2006. Hubungan antara konformitas dengan perilaku membeli impulsif pada remaja putri. Fakultas Psikologi Universitas Wangsa Manggala Yogyakarta, 1-12.

Basuki, J. 2018. Ekologi Administrasi Publik Di Indonesia Dalam Menghadapi Revolusi Industri 4.0: Perspektif Kebijakan Publik. Public Inspiration: Jurnal Administrasi Publik, 3(2), 53-62.

Febriantika, A., Sari, R. P., \& Hadining, A. F. (2019). Analisis Pengaruh Aspek Technology-Organization-Environment dalam Financial Technology terhadap Financial Inclusion UMKM Karawang. JURNAL TEKNIK INDUSTRI, 10(2), 170180.

Fryzia, A. (n.d.). gaya hidup remaja konsumtif. Kompsaiana.

Hurlock, Elizabeth b, Istiwidayanti, Sijabat, R. max. (1991). psikologi perkembangan: suatu pendekatan sepanjang rentang kehidupan (5th ed.). erlangga. 
Karim, A., Purnomo, H., Fikriyah, F., \& Kardiyati, E. N. 2020. A charismatic relationship: How a Kyai's charismatic leadership and society's compliance are constructed? Journal of Indonesian Economy and Business, 35(2), 129-143. https://doi.org/https://doi.org/10.22146/jieb.54705

Khoirunnas, K., \& Hidir, A. 2017. Pola konsumtif mahasiswa di Kota Pekanbaru. Riau University.

Lina, L., \& Rosyid, H. F. 1997. Perilaku konsumtif berdasarkan locus of control pada remaja putri. Psikologika: Jurnal Pemikiran Dan Penelitian Psikologi, 2(4), 5-14.

Mansir, F. 2017. Model Pendidikan Karakter Di Perguruan Tinggi Islam (Studi Pada Umi Dan Uin Alauddin Makassar).

Mansir, F. 2018a. Diskursus Pendidikan Karakter di Peguruan Tinggi Keagamaan Islam pada Era Milenial. Tadrib, 4(2), 280-300.

Mansir, F. 2018b. Pendekatan Psikologi Dalam Kajian Pendidikan Islam. Psikis: Jurnal Psikologi Islami, 4(1), 61-73.

Mansir, F. 2020. The impact of globalization on islamic education toward fiqh learning existence in covid-19 pandemic period. ATTARBIYAH: Journal of Islamic Culture and Education, 5(2), 123-133.

Mansir, F. 2021. Aktualisasi Pendidikan Agama dan Sains dalam Character Building Peserta Didik di Sekolah dan Madrasah. J-PAI: Jurnal Pendidikan Agama Islam, $7(2)$.

Mansir, F., \& Karim, A. 2020. Islamic education learning approaches in shaping students' emotional intelligence in the digital age. Hayula: Indonesian Journal of Multidisciplinary Islamic Studies, 4(1), 67-86.

Mansir, F., \& Syarnubi, S. 2021. Guidance And Counseling: The Integration Of Religion And Science In 21st Century For Character Building. At-Tarbiyat: Jurnal Pendidikan Islam, 4(2).

Monks, J. F., \& Knoers, A. M. P. 2014. Psikologi Perkembangan; Pengantar dalam berbagai bagiannya.

Mulyodiharjo, S. 2002. Terperangkap Dalam Iklan. Bandung: Alfabeta.

Nurjanah, S., Ilma, R. Z., \& Suparno, S. 2018. Effect of economic literacy and 
conformity on student consumptive behaviour. Dinamika Pendidikan, 13(2), 198207.

Qodriah, S. L., Hartati, W., \& Karim, A. 2019. Self-leadership and career success: Motivation of college lecturers. Journal of Leadership in Organizations, 1(2).

Rosyid, haryanto f. 1997. perilaku konsuntif berdasarkan locus of control. 4.

Rukajat, A. 2018. Pendekatan Penelitian Kualitatif (Qualitative Research Approach). Deepublish.

Santrock, J. W. 2011. Life-span development 13th edition. New York: McGraw-Hill. Schunk, DH (2005). Self-Regulated Learning: The Educational Legacy of Paul R. Pintrich. Educational Psychologist, 40(2), 85-94.

Sugiyono, D. 2013. Metode penelitian pendidikan pendekatan kuantitatif, kualitatif dan $R \& D$.

Sukari, S., Larasati, T. A., Mudjijono, M., \& Susilantini, E. 2013. Perilaku Konsumtif Siswa SMA Di Daerah Istimewa Yogyakarta. BPNB Yogyakarta: Yogyakarta.

Suzana, S., Munajim, A., Casta, C., Pratama, G., Sulaeman, E., Sukarnoto, T., Ridwan, M., \& Karim, A. 2020. Gadget and the internet for early childhood distance learning. PalArch's Journal of Archaeology of Egypt/Egyptology, 17(7), 80198028.

Trianto, M. P. 2010. Pengantar Penelitian Pendidikan Bagi Pengembangan Profesi Pendidikan \& Tenaga Kependidikan. Kencana, Jakarta. 